\section{sciendo}

DOI: 10.2478/BIPMF-2021-0005
BULETINUL INSTITUTULUI POLITEHNIC DIN IAŞI

Publicat de

Universitatea Tehnică „Gheorghe Asachi” din Iaşi Volumul 67 (71), Numărul 1, 2021

Secţia

MATEMATICĂ. MECANICĂ TEORETICĂ. FIZICĂ

\title{
SOME MECHANICAL PROPERTIES OF ARBOBLEND V2
}

\author{
DORIN VĂIDEANU ${ }^{1, *}$ and TUDOR-CRISTIAN PETRESCU ${ }^{2}$ \\ 1"Alexandru Ioan Cuza" University of Iaşi, \\ Department of Natural Sciences and Mathematics, Iaşi, Romania \\ 2"Gheorghe Asachi" Technical University of Iaşi, \\ Department of Mechanical Structures, Iaşi, Romania
}

Received: March 9, 2021

Accepted for publication: April 15, 2021

Abstract. The Arboblend V2 biopolymer composite with a matrix based on lignin behaves like a synthetic thermo-injectable polymer, so its use in various sectors does not involve additional costs for obtaining various objects, landmarks using installations injection, extrusion being used in case of synthetic polymers: polyethylene, polypropylene, etc. Compared to plastics obtained from finite sources (oil, natural gas etc.) this material has several specific properties that make it a viable replacement of plastics: it is obtained from renewable raw materials, it is biodegradable in various conditions and, if reinforced with other substances (e.g. Kevlar 3\%), becomes fireproof. Through the current paper, we determined the behavior of Arboblend V2 as a force of traction and a force shock. The results will lead to finding the best solutions for using Arboblend V2 and its specific properties that sets it apart from other materials.

Keywords: Arboblend; matrix; plastic; biocomposite; Young.

\section{Introduction}

Plastic waste represents a pressing, real and increasingly acute environmental and biotechnology problem. The discovery and effective use of

*Corresponding author; e-mail: naturaone@gmail.com

This is an Open access article licensed under the Creative Commons Attribution-Non Commercial

- No Dericatives 4.0 International License (CC BY-NV-ND 4.0) 
new biodegradable materials is an ongoing trend in all areas of activity. Because of the superior properties of plastics: materials and their biodegradability biocomposites could successfully replace some plastics in the near future, as well as some materials used in construction, anisotropic material properties composites have a structure based on multiple components, the development and organization it aims to make the best use of the best features of the components used (Rognoli et al., 2009-2010).

From the technical perspective, the concept of composite materials refers to materials that have the following properties: (1) artificially created by combining different components; (2) is a combination of at least two chemically different materials, between which a distinct separation surface is present; (3) has properties that any of the components cannot have, if considered separately.

Composite materials are made of a matrix (plastic, ceramic, metal) and the reinforcing elements (reinforced), which are arranged in matrix in different proportions and orientations. The reinforcement gives the composite material a high strength and represents the primary element of the load, and the matrix acts as a binding material between the reinforcing elements and the exterior environment of the load transfer to it. The two phases coexist, but generally do not react with each other and are chosen so as to be inert to one another in regular usage conditions. Biocomposites are biodegradable polymeric materials whose properties result from the components used. The qualities of the used components are mutually reinforcing, resulting in a material with better characteristics than that of any of the specific components.

The major and essential advantage of these composite materials consists in the modulation properties, thus obtaining a very large variety of materials, whose use may be extended in almost all areas of activity and not only technical. Polymer composites are materials basically composed of a macromolecular compound and a reinforcing agent or filler. By mixing together said elements, materials with outstanding mechanical strength can be obtained, capable of replacing plastics and derivatives. Macromolecular compound used for this purpose may be a thermoplastic polymer or thermosetting and is called polymer matrix. Reinforcing agent or the filler is homogeneously dispersed in the polymer matrix, but does not dissolve therein. Both components act synergistically. The individual components and the interface layer situated between them can be identified by physical methods and the behavior and properties of the interface influences and controls the properties of the composite material.

The properties exhibited by the composite material are totally different and superior to the ones of the individual components. Composite materials having natural constituents took the name of composites, including because of their biodegradability. There is already a relatively extensive use of various forms of liquid wood: handles, accessories, panels, chairs in the furniture industry, floors and various junction elements in constructions, toys, 
automotive, computers, telephones etc. Through the undertaken research, we aim at deepening the knowledge related to these innovative materials and expanding the potential use of various forms of "liquid wood", by knowing and using their physical properties (electric, magnetic, etc.) in the service of humanity. By using these types of materials which are environmentally friendly, it is limited the employment of plastics, so harmful biologically by their customary and prolonged presence in the environment.

\section{Technology and Research Plan}

In order to uncover the mechanical properties of liquid wood under the presentations, Arboblend V2 granules were injected, bought from Germany $\mathrm{GmbH}$ Tecnaro, molded into suitable specimens. Injection in the die of granules of "liquid wood" was done in accordance with the standard DIN EN ISO 527-: 1993 for obtaining the specimens using standard injection equipment SZ800H available in Precision Engineering and Nanotechnology Laboratory, Faculty of Machine Manufacturing and Industrial Management, "Gheorghe Asachi" Technical University of Iaşi.

The matrix was designed so that specimens have standard shape and size enabling their attachment between the benches of mechanical testing machines used (Menard, 1999).

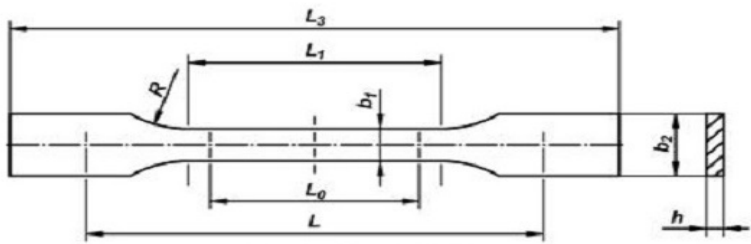

Fig. 1 - Dumbbell test piece according ISO 527 STAS.

Table 1

Specimen Dimensions

\begin{tabular}{|c|c|c||}
\hline \multirow{2}{*}{ Notations } & Characteristics & Dimensions \\
\hline \hline $\mathrm{L}_{3}$ & Total length & $\geq 150$ \\
\hline $\mathrm{L}_{1}$ & Length of narrow parallel sector & $60 \pm 0.5$ \\
\hline $\mathrm{R}$ & Radius & $\geq 60$ \\
\hline $\mathrm{b}_{2}$ & Width at the extremities & $20 \pm 0.2$ \\
\hline $\mathrm{b}_{1}$ & Width of narrow sector & $10 \pm 0.2$ \\
\hline $\mathrm{h}$ & Thickness & 2 până la $6^{*}$ \\
\hline $\mathrm{L}_{0}$ & Reference length & $50 \pm 0.5$ \\
\hline $\mathrm{L}$ & Initial distance between fasteners & $115 \pm 1$ \\
\hline
\end{tabular}


Injecting the material was accomplished as planned experimental research using the Taguchi method (Nedelcu et al., 2000, p.243-261). Taguchi method was imposed because it turned out to be more effective than other methods of planning experiences. It derives from the method of factorial experiments. Genichi Taguchi proposes another method for calculating the average effects of factors and interactions, this making it easier for mathematical modeling. Response to the question of reducing the amount of attempts resulted planes split method, which allows modeling with much less experience than the full plan method.

Plan of experiments: Taguchi is one of the split planar methods; even more, it has the advantage that it is convenient to use in practice (Nedelcu et al., 2000, p.243-261). In determining the number of experiments involving the examination of a phenomenon by that method, several restrictive conditions must be observed: (1) orthogonality rule, according to which the smallest number of experiences of a plan must be lower than the lowest common multiple of disjoint levels and interactions; (2) rule of freedom degrees, in accordance with the minimum number of experiments conducted equals the number of freedom degrees of the model studied; (3) rule of identities refers to situations when the shares of factors or some interactions to be mistaken with others.

Table 2

Values Levels of Variation of Parameters

\begin{tabular}{||c|c|c|c|c|c|c||}
\hline $\begin{array}{c}\text { Arboblend } \\
\mathrm{V} 2\end{array}$ & $\begin{array}{c}\mathrm{T}_{\text {top }} \\
{\left[{ }^{\circ} \mathrm{C}\right]}\end{array}$ & $\begin{array}{c}\alpha_{\text {inj }} \\
\text { grade] }\end{array}$ & $\begin{array}{c}\mathrm{P}_{\text {inj }} \\
{[\mathrm{MPa}]}\end{array}$ & $\begin{array}{c}\mathrm{t}_{\text {inj }} \\
{[\mathrm{s}]}\end{array}$ & $\begin{array}{c}\mathrm{t}_{\mathrm{r}} \\
{[\mathrm{s}]}\end{array}$ & $\begin{array}{c}\mathrm{V}_{\text {inj }} \\
{[\mathrm{m} / \mathrm{min}]}\end{array}$ \\
\hline \hline 1 & 140 & 0 & 70 & 6 & 18 & 60 \\
\hline 2 & 140 & 0 & 70 & 6 & 25 & 80 \\
\hline 3 & 140 & 0 & 90 & 9 & 18 & 80 \\
\hline 4 & 140 & 90 & 90 & 6 & 25 & 80 \\
\hline 5 & 140 & 90 & 90 & 6 & 18 & 60 \\
\hline 6 & 140 & 90 & 70 & 9 & 25 & 60 \\
\hline 7 & 140 & 90 & 70 & 9 & 25 & 60 \\
\hline 8 & 140 & 90 & 70 & 9 & 18 & 80 \\
\hline 9 & 155 & 0 & 90 & 9 & 18 & 60 \\
\hline 10 & 155 & 0 & 90 & 9 & 25 & 80 \\
\hline 11 & 155 & 0 & 70 & 6 & 18 & 80 \\
\hline 12 & 155 & 0 & 70 & 6 & 25 & 60 \\
\hline 13 & 155 & 0 & 90 & 6 & 18 & 80 \\
\hline 14 & 155 & 90 & 70 & 9 & 25 & 80 \\
\hline 15 & 155 & 90 & 70 & 9 & 18 & 60 \\
\hline 16 & 155 & 90 & 90 & 6 & 25 & 60 \\
\hline
\end{tabular}

The research plan of injection includes a total of 16 experiments, and for each experiment with the same parameter value, 3 injections were carried out, L-type fractional plan. The materials used were Arboblend V2 table that 
contain tier values of variation in the input parameters are shown below (Table 2). In Table 2: $\mathrm{T}_{\text {top }}$ - melting temperature, $\left[{ }^{\circ} \mathrm{C}\right] ; \alpha_{\mathrm{inj}}-$ angle at which the injection is made, [grade]; $\mathrm{P}_{\mathrm{inj}}$ - injection pressure, $\left[\mathrm{MPa}\right.$ ]; $\mathrm{t}_{\mathrm{inj}}$ - injection time, $[\mathrm{s}] ; \mathrm{t}_{\mathrm{r}}-$ cooling time, [s]; $\mathrm{V}_{\text {inj }}$ - injection speed, [m/min].

Determination of traction resistance. Single-axle tensile tests were carried out on ZWIEK- Roell universal testing machine. The device runs the software Work4-MTS Tensile Test Erica using a test speed of $0.1 \mathrm{~mm} / \mathrm{min}$ for "liquid wood" - variants studied, data acquisition rate is $10 \mathrm{~Hz}$, in the Faculty of Materials Science and Engineering the Polytechnic University of Cluj-Napoca.

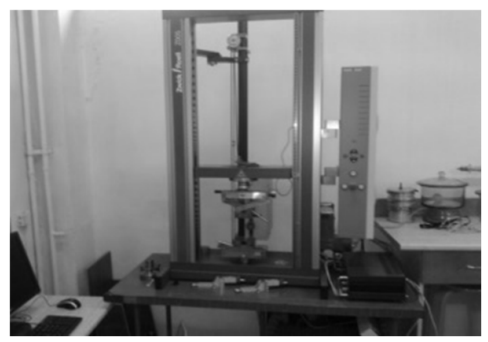

Fig. 2 - Universal testing machine ZWICK- Roell 2005.

Table 3

Calculus Relations Employed for Traction Tests

\begin{tabular}{||c|l||}
\hline$\sigma=\frac{F}{A}$ & $\begin{array}{l}\sigma-\text { resistance, }(\mathrm{MPa}) \\
F-\text { force, }(\mathrm{N}) \\
A-\text { specimen section area, }\left(\mathrm{cm}^{2}\right)\end{array}$ \\
\hline$E=\frac{F \cdot l_{0}}{A \cdot d}$ & $\begin{array}{l}E-\text { elasticity modulus/ Young's modulus, }(\mathrm{MPa}) \\
l_{\mathrm{o}}-\text { initial length, }(\mathrm{mm})\end{array}$ \\
\hline $\bar{d}=d-\frac{n}{m}$ & $\begin{array}{l}\bar{d}-\text { average value of elongation at breakage, }(\mathrm{mm}) \\
n-\text { initial loading, }(\mathrm{N}) \\
m-\text { slope },(\mathrm{N} / \mathrm{mm})\end{array}$ \\
\hline$\varepsilon=\frac{\bar{d}}{l_{0}} \cdot 100$ & $\begin{array}{l}\varepsilon-\text { relative elongation, }(\%) \\
d-\text { elongation at breakage, }(\mathrm{mm})\end{array}$ \\
\hline
\end{tabular}

The modulus of elasticity is one of the key specific characteristics of solid materials. In the case of polymeric biocomposites, the factors that influence Young's modulus are multiple and complex: the nature of the matrix and the reinforcement, the compatibility between them, the processing technology for the material and the working environment, the distribution of the reinforcement in the matrix at interface structure and morphology etc.

For the modulus of elasticity $E_{f}$, the calculus relation is:

$$
E_{f}=\frac{L^{3} m}{4 b h^{3}}
$$


Where: $E_{f}$ - elasticity modulus, $(\mathrm{MPa}) ; L$ - distance between fasteners, $(\mathrm{mm}) ; b$ - width of the specimen, (mm); $h$ - thickness of the specimen, (mm); $m$ - the gradient (for example, the slope) of the early segment of the straight line, deformation curve due to loading, $(F / l),(\mathrm{N} / \mathrm{mm})$ (Florea et al., 2012, p.59-65, Burgueno et al., 2005, p.87-91).

The conditions at which measurements were performed, were at room temperature $\mathrm{T}=210 \mathrm{C}$, the traction speed $\mathrm{v}=5.0 \mathrm{~mm} / \mathrm{min}$, initial sample length $=59.792 \mathrm{~mm} \mathrm{~L} 0 \approx 60 \mathrm{~mm}$.

Determination of Shock Resistance. The shock testing of thermoplastic materials is done according to SR EN ISO 179:2000 and SR EN ISO 180: 2000 standards, with the aim of determining their ductility or brittleness. The test consists from the balancing/oscillation of a big and heavy hammer on a pendulum from a pre-determined height, Fig. $3 a$. When the hammer arrives in the inferior sector of the pendulum curve, the specimen is hit and fractured, Fig. $3 b$. The equipment used to obtain the shock resistance measures the impact energy "taken in" by the specimen during the breakage, as the difference between the potential energy of the pendulum in its initial and final position, after the breakage of the specimen the consumed energy being thus registered (Brown, 2002).

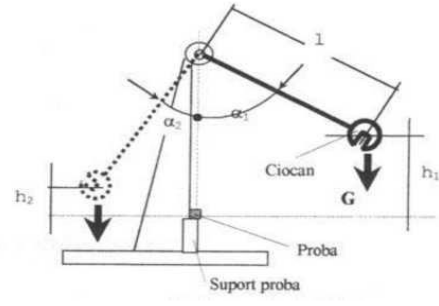

$a$

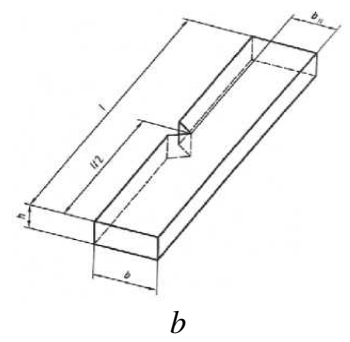

Fig. 3 - (a) Charpy hammer layout; (b) Notched specimen, shock testing.

The Charpy shock resistance is computed using the formula

$$
\mathrm{a}_{\mathrm{cU}}=\frac{E_{C}}{h b_{N}} 10^{3}
$$

where: $E_{c}$ - absorbed energy at specimen breakage, $(\mathrm{J}) ; h$ - thickness of tested specimen $(\mathrm{mm}) ; b_{N}$ - remaining specimen width of tested specimen after notching (mm) (Harper, 2006).

The shock resistance of "liquid wood" specimens is affected by: humidity, hammer speed, hammer energy, specimen geometry, striking angle and direction, specimen preparing (obtained by material injection), the fastening of the specimen in the testing equipment.

The testing parameters used in determining shock resistance were: speed $=3.0 \mathrm{~m} / \mathrm{s}$, weight $=1.190 \mathrm{~kg}$, energy $=5 \mathrm{~J}$, room temperature $-21^{\circ} \mathrm{C}$. 
Collected data was introduced in Origin Pro 9.0 software, which generated a collection of graphs which allowed some interpretations on the behavior and tensile mechanical of Arboblend V2. Below, results are shown, that have generated charts and conclusions regarding the optimal conditions for obtaining a resilient injection, increased traction and a possible change in internal structure of materials is form of resistance of materials to mechanical action of an external factor.

\section{Results and Discussions}

From the processing of the experimental results (Table 4), it can be stated: Arboblend V2 highest tensile strength was recorded on the sample 6 and the injection conditions were as follows: melting temperature $=155^{\circ} \mathrm{C} \mathrm{T}_{\text {top }}$, angle $\alpha=0^{\circ}$ injection, injection pressure $\mathrm{P}_{\mathrm{inj}}=90 \mathrm{MPa}$, fainted during injection $=6 \mathrm{~s}$, cooling time $\mathrm{t}_{\mathrm{r}}=18 \mathrm{~s}$ and $\mathrm{V}_{\text {inj }}$ injection speed $=80 \mathrm{~m} / \mathrm{min}$.

Table 4

Values Levels of Variation of Parameters for Arboblend V2

\begin{tabular}{|c|c|c|c|c|c|c|c|c|c|}
\hline $\begin{array}{c}\text { Arboblend } \\
\text { V2 } \\
\end{array}$ & $\begin{array}{c}\mathrm{T}_{\text {top }} \\
{\left[{ }^{\circ} \mathrm{C}\right]}\end{array}$ & $\begin{array}{c}\alpha_{\mathrm{inj}} \\
\text { [grade] }\end{array}$ & $\begin{array}{c}\mathrm{P}_{\text {inj }} \\
{[\mathrm{MPa}]}\end{array}$ & $\begin{array}{l}t_{\text {inj }} \\
{[s]}\end{array}$ & $\left.\begin{array}{c}\mathrm{t}_{\mathrm{r}} \\
{[\mathrm{s}]}\end{array}\right]$ & $\begin{array}{c}\mathrm{V}_{\mathrm{inj}} \\
{[\mathrm{m} / \mathrm{min}]}\end{array}$ & $\begin{array}{c}\sigma \\
{[\mathrm{MPa}]} \\
\end{array}$ & $\begin{array}{c}\varepsilon \\
{[\%]}\end{array}$ & $\begin{array}{c}\mathrm{E} \\
{[\mathrm{MPa}]} \\
\end{array}$ \\
\hline 1 & 140 & 0 & 70 & 6 & 18 & 60 & 146.6 & 4.15 & 3530.20 \\
\hline 2 & 140 & 0 & 70 & 6 & 25 & 80 & $\mid 172.3$ & 5.23 & 3290.16 \\
\hline 3 & 140 & 0 & 90 & 9 & 18 & 80 & \begin{tabular}{|l}
191.4 \\
\end{tabular} & 4.71 & 4060.26 \\
\hline 4 & 140 & 90 & 90 & 6 & 25 & 80 & 271.1 & 6.23 & 4340.76 \\
\hline 5 & 140 & 90 & 90 & 6 & 18 & 60 & 165.8 & 4.48 & 3690.85 \\
\hline 6 & 140 & 90 & 70 & 9 & 25 & 60 & 183.2 & 4.65 & 3930.68 \\
\hline 7 & 140 & 90 & 70 & 9 & 25 & 60 & 278.3 & 5.87 & 4730.80 \\
\hline 8 & 140 & 90 & 70 & 9 & 18 & 80 & 269.0 & 5.96 & 4510.27 \\
\hline 9 & 155 & 0 & 70 & 6 & 18 & 60 & 156.7 & 4.25 & 3540.22 \\
\hline 10 & 155 & 0 & 70 & 6 & 25 & 80 & 182.4 & 5.33 & 3300.18 \\
\hline 11 & 155 & 0 & 90 & 9 & 18 & 80 & 201.5 & 4.81 & 4070.28 \\
\hline 12 & 155 & 90 & 90 & 6 & 25 & 80 & 281.2 & 6.33 & 4350.78 \\
\hline 13 & 155 & 90 & 90 & 6 & 18 & 60 & 175.9 & 4.58 & 3700.87 \\
\hline 14 & 155 & 90 & 70 & 9 & 25 & 60 & 193.3 & 4.75 & 3940.70 \\
\hline 15 & 155 & 90 & 70 & 9 & 25 & 60 & 288.4 & 5.97 & 4740.82 \\
\hline 16 & 155 & 90 & 70 & 9 & 18 & 80 & 279.1 & 6.06 & 4520.29 \\
\hline
\end{tabular}


In Figs. $4 a, b, c$ the distribution graphs describing the characteristic values studied in the traction tests are presented.

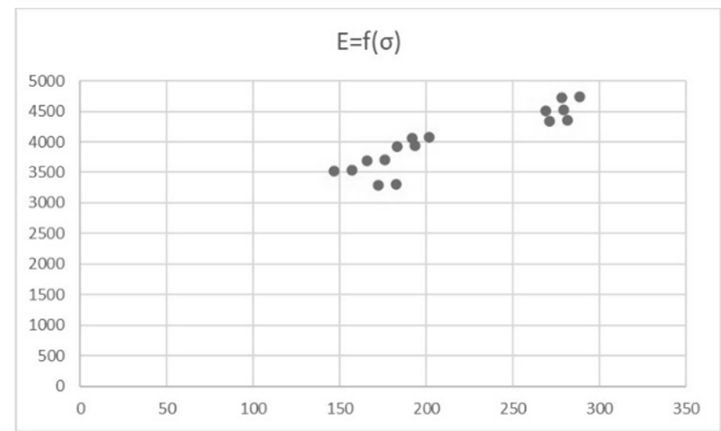

$a$

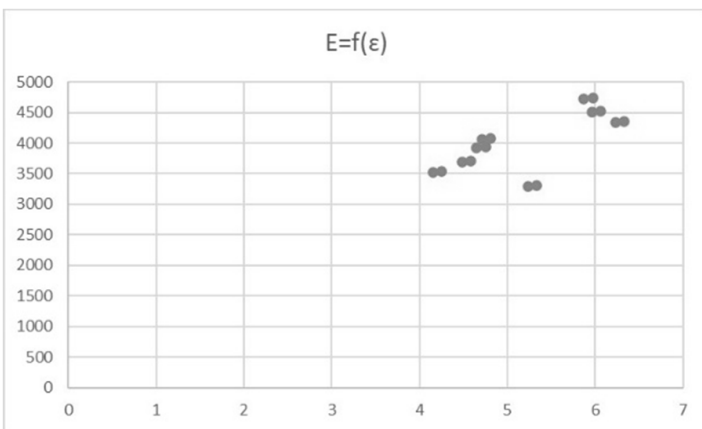

$b$

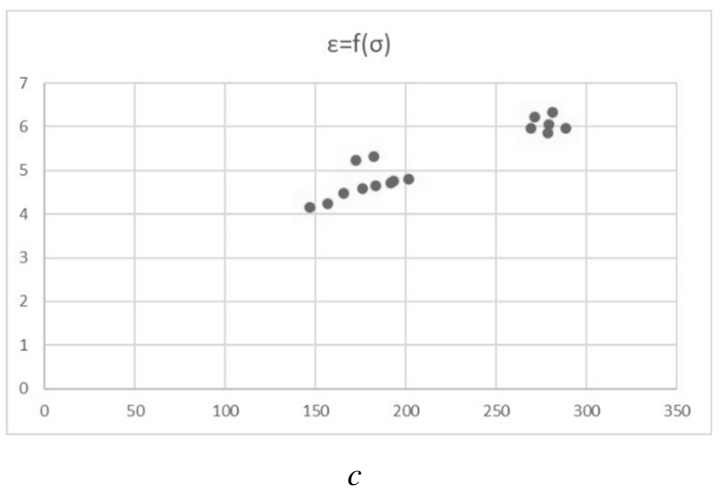

Fig. $4-(a)$ The distribution of the traction test results

(E vs. $\left.\sigma_{\max }\right)$ for Arboblend V2; $(b)$ The distribution of the traction test results (E vs. $\left.\varepsilon_{\max }\right)$ for Arboblend V2; $(c)$ The distribution of the traction test results $\left(\sigma_{\max }\right.$ Vs. $\varepsilon$ ) for Arboblend V2. 
In Fig. 5 the variation graphs of the elastic force as a dependence of elongation $\Delta \mathrm{l}$ can be observed.

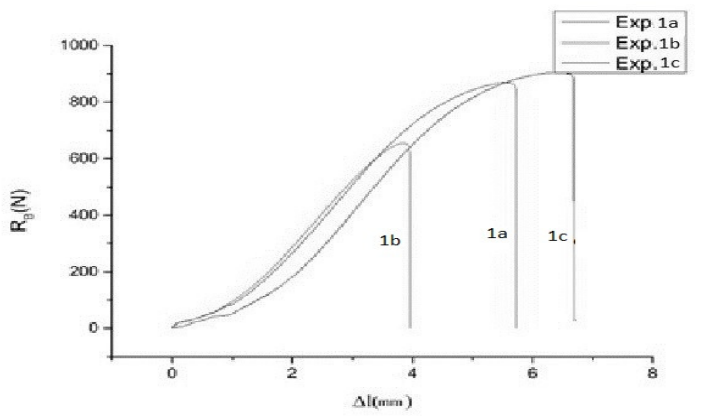

Fig. 5 - The variation of elastic force as a dependence of the relative elongation.

Arboblend V2 sample (exp.1).

Another important observation is the appearance of properties of those quasielastic materials to the occurrence of external forces. From the processing of charts, we noticed that certain parameters for injection are observable, and for small forces appear inflection points -for a certain amount of deforming force and to a certain relative elongation value. This aspect can be described starting from the chemical composition communicated by the manufacturer, who stated that the substance with the highest percentage of material is lignin. It is recognized that lignin is the substance that gives hardness to wood fiber, at the same time molecule lignin is a complex molecule formed by coupling three macromolecules (Fetecău, 2009, p.127-139).

The conclusion of having these inflection points can be described by resistance to deformation of the material that is on the spatial rearrangement of the lignin molecules which seek to shorten the chemical bonds between atoms. (Fig. 6).

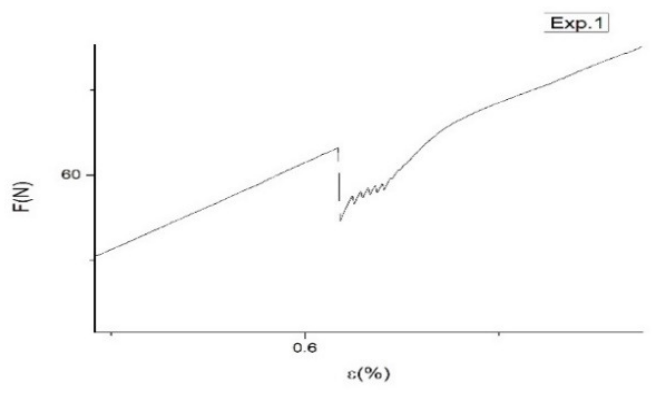

Fig. 6 - Details with inflection points on the graph in

Fig. 4 Arboblend V2 sample. 
Table 5

Shock Resistance of Arboblend V2 Specimens

\begin{tabular}{|c|c||}
\hline Experiment & $\begin{array}{c}\text { Charpy shock resistance } \\
\left(\mathrm{kJ} / \mathrm{m}^{2}\right)\end{array}$ \\
\hline \hline E1 & 0.43 \\
\hline E2 & 0.85 \\
\hline E3 & 0.43 \\
\hline E4 & 1.28 \\
\hline E5 & 1.82 \\
\hline E6 & 1.37 \\
\hline E7 & 1.74 \\
\hline E8 & 2.14 \\
\hline E9 & 1.77 \\
\hline E10 & 1.73 \\
\hline E11 & 1.69 \\
\hline E12 & 0.86 \\
\hline E13 & 1.31 \\
\hline E14 & 1.38 \\
\hline E15 & 1.88 \\
\hline E16 & 0.40 \\
\hline
\end{tabular}

From analysing the graph in Fig. 7, the shock resistance values variation can be noticed, these being influenced by the injection parameters of studied materials.

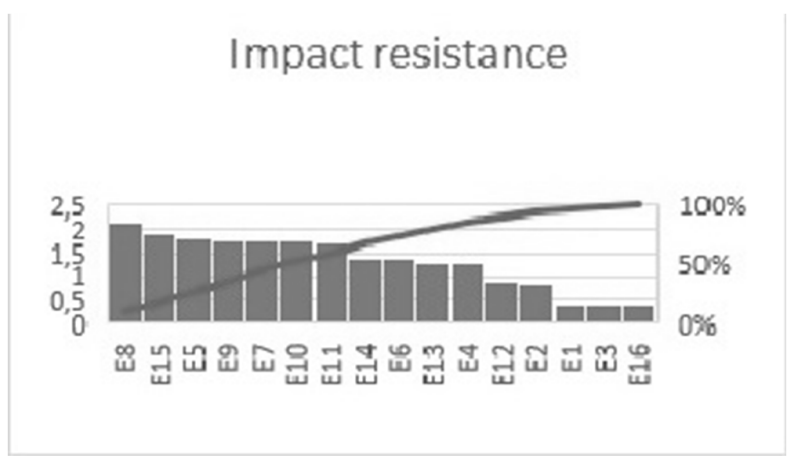

Fig. 7 - Diagram of shock resistance for Arboblend V2.

The difference in shock resistance can be clarified by the way the lignin matrix is settled, due to injection conditions. It is known that lignin is the substance that provides hardness to the wood fibre. This viscoelastic hardness is indicated by the fact that the lignin molecule is a complex one, this being 
further composed of three more complex molecules which, when subjected to the external deformation factors, seek to shorten the chemical bonds between them, in such a way that the final lignin molecule may occupy the same volume.

Depending on the injection settings (especially the orientation of the injection angle) the link between the quantities of the viscoelastic properties and the way the lignin molecular chain is set up, transversally or longitudinally, may be observed. This aspect can be of help when various parts from the material are mechanically cut, as no significant internal structural changes take place.

\section{Conclusions}

Conclusions resulting from the studies regarding the mechanical performance for Arboblend are: (1) experimental data show the fact that the material is viscoelastic; (2) this characteristic is because of the mixed crystalline - amorphous structure (Arboblend V2) at normal temperatures (Puiu Costescu et al., 2016); (3) the mechanical performance of these recently developed materials recommends them for usage as ecologic materials, in the place of synthetic plastics, which are present virtually everywhere; these biocomposites may be considered in the category of brittle materials, presenting the same elongation and breakage limits; (4) from a first analysis it can be certainly said that the lignin molecular chain and its positioning in regard to the direction of action of the external mechanical force, influences the viscoelastic properties; (5) the modification in time of the dimensions of some specimens may be justified by a flowing phenomenon with a very high viscosity coefficient, which decreases as temperature increase; (6) an increase of mechanical resistance of the studied materials is possible by improving the injection parameters, especially the injection angle. Hooke's law

Because liquid wood can be assimilated to a complex system, the usual

$$
\sigma=E \varepsilon
$$

must be replaced by a power law type:

$$
\bar{\sigma}=\bar{E}(\bar{\varepsilon})^{\alpha}
$$

where $\bar{\sigma}$ corresponds to a fractal tension, $\bar{\varepsilon}$ corresponds to a fractal deformation, $\bar{E}$ represents the equivalent Young's modulus, and $\alpha$ is a factor related to the degree of fractality fractional curves of elongation (Nottale, 2011).

Because $\bar{\sigma}, \bar{\varepsilon}$ are fractal variable, respectively $\bar{E}$ fractal coefficient type Young, they will be complex sizes. Their real part is differentiable but also independent of scale resolution, the imaginary part is not differentiable and is dependent on the resolution scale. 
Moreover, $\bar{\sigma}$ and $\bar{\varepsilon}$ are qunatities simultaneously invariant with respect to spatio-temporal transformations, and with respect to the scale transformations (Merchess et al., 2016). So that in a certain context occurrence of inflection "points" changes are nothing more than the degree of fractalization flow curves.

\section{REFERENCES}

Brown J., Handbook of Polymer Testing - Short-Term Mechanical Tests, Rapra Technology Limited, ISBN 1-85957-324-X, 2002.

Burgueno R., Quagliata M.J., Mehta G.M., Mohanty A.K., Misra M., Drzal L.T., Sustainable Cellular Biocomposites from Natural Fibers and Unsaturated Polyester Resin for Housing Panel Applications, Journal of Polymers and the Environment, 13, 2, April 2005, 87-91 (2005).

Fetecău C., Cercetări privind reologia aplicată la injectarea multi-component a naterialelor polimerice. Analiza procesului de injectare multi-component Raport publicabil, decembrie 2009, Universitatea "Dunărea de Jos" din Galați, 127-139.

Florea R.M., Carcea I., Polymer Matrix Composites-Routes and Properties, Int. J. of Modern Manufact. Technol., IV, 1, 59-65 (2012).

Harper C.A., Handbook of Plastics Technologies - The Complete Guide to Properties and Performance, The McGraw-Hill Companies, ISBN: 9780071460682, 2006.

Menard K.P., Dynamic Mechanical Analysis: A Practical Introduction, Edited by K.P. Menard, CRC Press LLC, U.S. (1999).

Mercheș I., Agop M., Differentiability and Fractality in Dynamics of Physical Systems, World Scientific, 2016.

Nedelcu D., Pruteanu O., Aspecte ale formării canelurilor exterioare prin deformare plastică la rece utilizând metoda Taguchi, Editura Tehnica-Info, Chișinău, 243-261 (2000).

Nottale L., Scale Relativity and Fractal Space-Time, World Scientific Publishing Co. Pte. Ltd. (2011).

Puiu Costescu E., Nedelcu D., Leontie L., Dumitras M., Asănduleasa M., Văideanu D., Agop M., The Termodinamic Behavior of Liquid Wood, International Journal of Modern Manufacturing Technologies, I (2016).

Rognoli V., Salvia G., Manenti S., Un'identita' per ibiopolimeri: il caso del legnolichido, 2009-2010.

\section{UNELE PROPRIETĂŢI MECANICE ALE ARBOBLEND V2}

(Rezumat)

Compozitul biopolimer Arboblend V2 are o matrice pe bază de lignină şi se comportă ca un polimer sintetic termo-injectabil, astfel încât utilizarea sa în diverse sectoare nu implică costuri suplimentare pentru obținerea diverselor obiecte, repere 
folosind instalațiile de injecție, extrudarea, care sunt utilizate şi în cazul materialelor sintetice polimeri: polietilenă, polipropilenă etc. În comparație cu materialele plastice obținute din surse finite (petrol, gaze naturale etc.), acest material are mai multe proprietăți specifice, care îl fac a fi o înlocuire viabilă a materialelor plastice: este obținut din materii prime regenerabile, este biodegradabil în diferite condiții și, dacă este întărit cu alte substanțe (de exemplu Kevlar 3\%), devine ignifug. În această lucrare am determinat comportamentul Arboblend V2 supus la acţiunea unei forțe de tracțiune și la un şoc forțat. Rezultatele obţinute conduc la găsirea celor mai bune soluții pentru utilizarea Arboblend V2 pe baza proprietăților sale specifice, care îl diferențiază de alte materiale. 